(u)-a ペルオキシドとの反応性がポリスルフィドよ ク小さいもの; $\mathrm{Cr}, \mathrm{Al}, \mathrm{Ni}$

(u)-b ペルオキシドとの反応性がポリスルフィドよ り大きいもの; $\mathrm{Fe}, \mathrm{Cu}, \mathrm{V}, \mathrm{Mn}, \mathrm{Co}$

(ii) ゴムのペルオキシドの分子切断反応を促進する の; Mo, $\mathrm{Pb}, \mathrm{Zn}$

(iit)-a ペルオキシドとの反応性がポリスルフィドよ り小さいもの; $\mathrm{Zn}, \mathrm{Pb}$

(u)-b ペルオキシドとの反応性がポリスルフィドよ り大きいむの; Mo

なお，天然ゴムのヒドロペルオキシドは，ポリブタジ エンのそれよりも分解しや寸いことがわかった.

\section{引用文献}

1) R. M. Russell, T. D. Skinner, A. A. Watson:

Rubber Chem. Technol., 42, 418 (1969)
2) L. H. Lee, C. L. Stacy, R. G. Engel: J. Appl. Polymer Sci., 10, 1699 (1966)

3) W. R. May, L. Bsharan: Ind. Eng. Chem. Prod. Res. Develop., 9, 73 (1970)

4) 村上謙吉, 田村三郎：工化誌, 73, 574 (1970)

5) 山下晋三, 岩田正弘, 䊝谷信三: 日払劦誌, 49, 663 (1976)

6) G. T. Morgan, R. A. S. Castell: J. Chem. Soc., 3252 (1928)

7) Inorg. Syn., 5, 113, McGraw-Hill Book Company, Inc., New York (1953)

8) P. J. Flory, J. Rehner, Jr.: J. Chem. Phys., 11, 512 (1943)

9) A. F. Bickel, E. C. Kooyman: J. Chem. Soc., 2215 (1956), 2217 (1957)

10) 西川幸利, 大津隆行: 工化誌, 72, 751 (1969)

11) 增尾富士雄：工化誌，67, 1113 (1964)

\title{
INFLUENCE OF CHELATED COMPOUNDS ON THE OXIDATION OF DIENE RUBBER
}

\section{Shinzo YAMASHITA and Nariyoshi KAWABATA (Department of Chemistry, kyoto Institute of Technology; Matsugasaki, Sakyo-ku, Kyoto 606, Japan) Masahiro IWATA (Ouchishinko chemical Industrial Co., Ltd., Prsent address. Pentru Co. Ltd., Central Research Labaratory, 1-8, Yoshimachi 4 chome, Soka-shi, Saitama 340, Japan)}

The influence of eleven metal acetylacetonates on the oxidation of diene rubber were studied. The rubbers used for this study were BR and NR vulcanized by peroxide or sulfur. Decomposition of peroxides and autoxidation of tetralin under the influence of the metal acetylacetonates were also studied. Metal acetylacetonates were found to be classified to the following three types: (i) gives radicals by self-decomposition and initiates the degradation of rubber; (ii) reacts with hydroperoxides to form radicals; (iii) reacts with polymer hydroperoxides to result in the main chain scission of polymers.

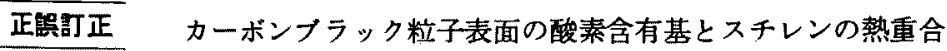

大北熊一, 坪川紀夫, 斎藤英一, 野田雅之, 江口宏喜, 本誌, 49, No.12 (1975)

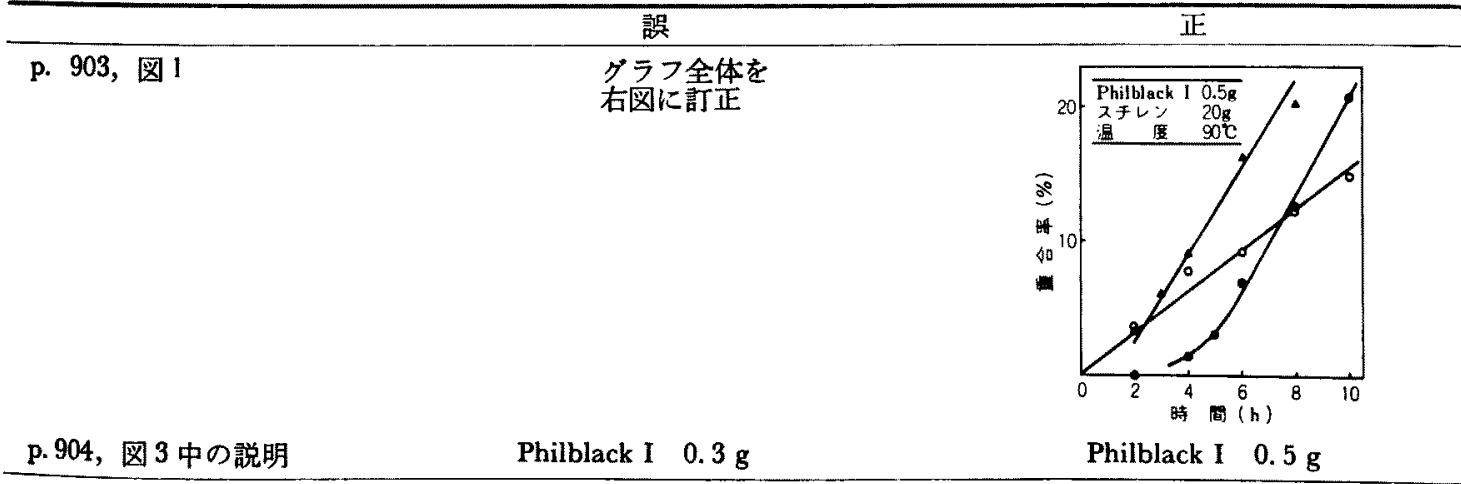

